\title{
OPEN Evidence of wet-dry cycles and mega-droughts in the Eemian climate of southeast Australia
}

\author{
Hamish McGowan ${ }^{1 凶}$, Micheline Campbell ${ }^{2}$, John Nikolaus Callow ${ }^{2}$, Andrew Lowry ${ }^{1}$ \& \\ Henri Wong ${ }^{3}$
}

Understanding past climate variability is critical to informing debate of likely impacts of global warming on weather and climate, and water resources. Here we present a near annual resolution reconstruction of climate developed from a speleothem that spans the Eemian [Marine Isotope Stage 5e (MIS 5e)] from 117, 500 to 123,500 years BP-the most recent period in the Earth's history when temperatures were similar to those of today. Using ${ }^{25} \mathrm{Mg},{ }^{88} \mathrm{Sr}$, and ${ }^{137} \mathrm{Ba}$ as proxies, we show the first indication of solar and teleconnection cyclic forcing of Eemian climate in southeast Australia, a region at present often affected by severe drought and bushfires. We find evidence for multi-centennial dry periods interpreted as mega-droughts, and highlight the importance of understanding the causes of these in the context of a rapidly warming world, where temperatures are now, or projected to exceed those of the Eemian.

The Eemian or peak of the Last Interglacial [Marine Isotope Stage 5e (MIS 5e); ca. 129,000-116,000 years Before Present (BP)] is the most recent geologic period when global temperatures were similar to present, but in response to orbital forcing rather than greenhouse gas loading of the atmosphere. While this makes the Eemian an imperfect analogue for near-future climate due to anthropogenic global warming, the latitudinal temperature distribution was similar to the present ${ }^{1-4}$. Eemian global mean temperature was $0-2{ }^{\circ} \mathrm{C}$ warmer than present, mean global sea surface temperatures (SSTs) were indistinguishable from current SSTs ${ }^{5}$, though sea level was around 6-9 $\mathrm{m}$ higher from meltwater inflows from the Greenland and Antarctic ice sheets. Therefore, understanding the climate of the Eemian may provide valuable insight to future climate and its variability.

While often thought of as a period of relative climate stability, climate variability during the Eemian was likely greater than in the Holocene. This has been attributed to meltwater outflows disturbing the Atlantic meridional overturning circulation (AMOC) $)^{6,7}$ and a general global cooling trend toward glacial inception ${ }^{8}$. The resulting changes in sea surface salinity and temperature are believed to have driven regional changes in atmospheric circulation leading to periods of widespread aridity across Europe ${ }^{6}$, and onset of abrupt cold periods as SSTs cooled by several degrees Celsius ${ }^{6,9}$.

Our understanding of Southern Hemisphere Eemian climate is limited as proxy records are rare. The climate of Australia is globally relevant, as it responds to key global teleconnection forcing, including El Niño Southern Oscillation (ENSO), Pacific Decadal Oscillation (PDO) and the Indian Ocean Dipole (IOD). It is also relevant as the severity of recent droughts and bushfires have been linked to increasing temperatures caused by anthropogenic greenhouse gas emissions $s^{10-13}$, thereby stimulating interest in understanding past warm climate conditions such as during MIS $5 \mathrm{e}$.

Numerical modelling studies suggest reduced seasonal contrast in MIS 5e temperatures across Australia with warmer winter temperatures, most notably in the north and northwest of the continent by $+3{ }^{\circ} \mathrm{C}$ to $+5^{\circ} \mathrm{C}^{14}$. Austral summer (December-February) temperatures are believed to have been cooler by $-1{ }^{\circ} \mathrm{C}$ to $-2{ }^{\circ} \mathrm{C}$ with modelling studies suggesting that the Australian monsoon was weaker and drier than present with JanuaryApril precipitation anomalies of $>-3 \mathrm{~mm}$ per day ${ }^{14,15}$. A weaker MIS $5 \mathrm{e}$ monsoon aligns with evidence of a variable Lake Eyre hydrology with temporally isolated small inflow events ${ }^{16}$. These were likely caused by irregular southward penetration of the Intertropical Convergence Zone (ITCZ) and decaying tropical cyclone(s) over the headwaters of the Lake Eyre Basin-conditions similar to those of today that deliver inflows to Lake Eyre.

Winter temperatures in southern Australia during MIS 5e are believed to have been warmer than present, reflecting warmer SSTs in the Southern Ocean. This would have reduced the meridional temperature gradient

\footnotetext{
${ }^{1}$ Atmospheric Observations Research Group, The University of Queensland, Brisbane, Australia. ${ }^{2}$ School of Agriculture and Environment, The University of Western Australia, Perth, Australia. ${ }^{3}$ Australian Nuclear Science and Technology Organisation, Lucas Heights, Sydney, Australia. ${ }^{\circledR}$ email: h.mcgowan@uq.edu.au
} 
(a)

(b)
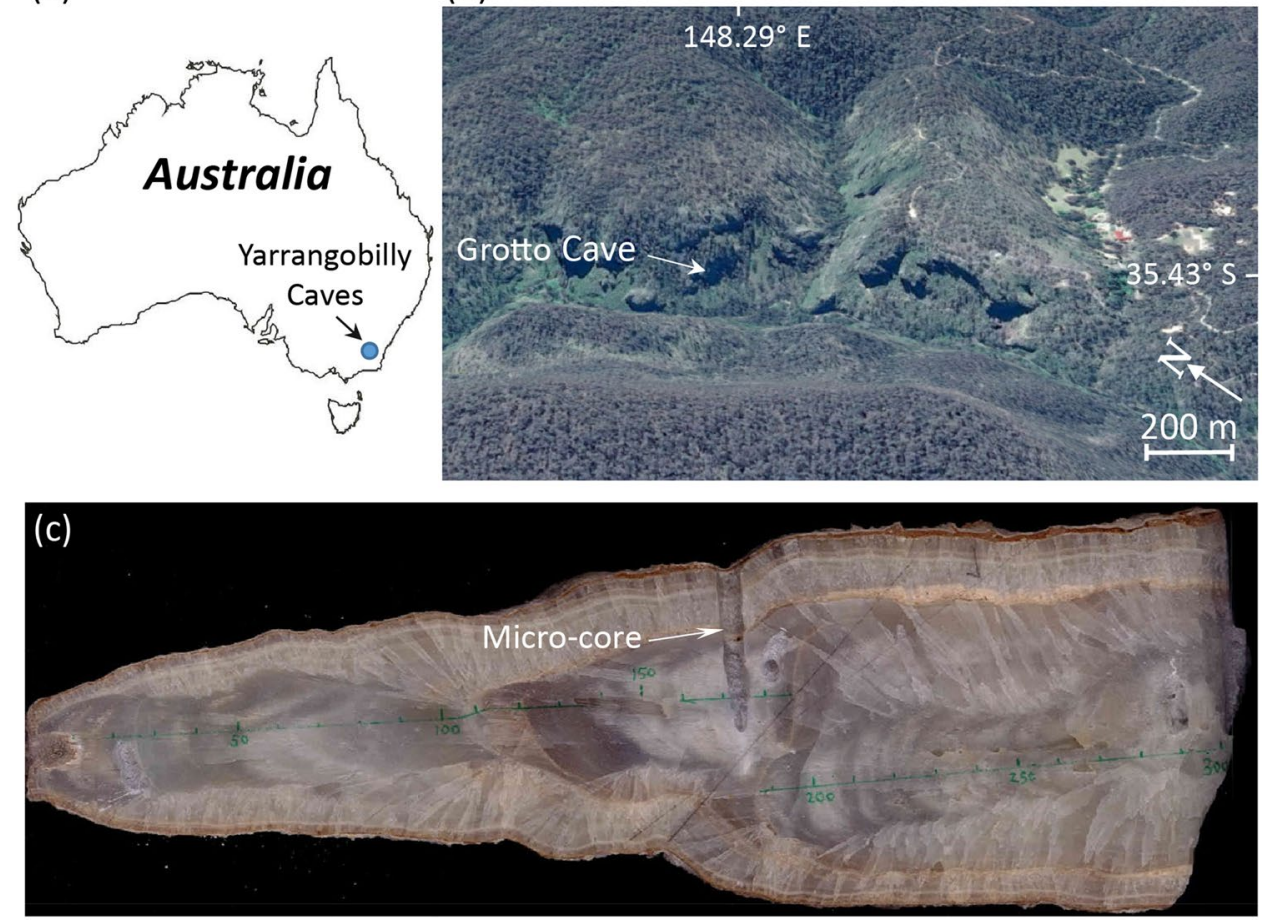

Figure 1. Location map of the Yarrangobilly Caves (a) and aerial oblique perspective of the entrance to the Grotto Cave created using Google Earth Pro 7.3 (Google Earth, earth.google.com/web/) (b). 300 mm long cross-section of stalagmite GC001 from which samples were extracted for uranium series dating (see Table S1) and geochemical analysis (c). The small core perpendicular to the growth axis is the result of in-situ sampling of GC001 for age determination prior to removal from the Grotto Cave (c).

between the sub-tropics and mid/high latitudes with less frequent precipitation bearing cold fronts and extratropical depressions at a time concurrent with strengthening of interannual variability of SSTs in the eastern tropical Pacific associated with ENSO ${ }^{17}$. Slightly cooler MIS 5e SSTs to the northwest of Australia relative to present $^{5,18}$ may have contributed further to reduced rainfall over southeast Australia similar to the impact of present day positive IOD events ${ }^{19}$. Combined with changes to AMOC and associated SSTs, which have been shown under present day conditions to teleconnect to the Pacific Ocean ${ }^{20}$, the climate of MIS 5e in Australia is likely to have been variable, but in general drier than present. In particular, in southeast Australia where under the current climate positive IOD and ENSO result in reduced rainfall ${ }^{20-22}$. However, a dearth of high temporal resolution paleoclimate records from MIS $5 \mathrm{e}$ have until present not been available to test this thesis and the possible links to climate state forcings such as teleconnections and solar variability.

In Australia, speleothems offer the greatest potential to develop high temporal resolution terrestrial paleoenvironmental records. Stalagmite GC001 was removed from a small chamber approximately $60 \mathrm{~m}$ into the Grotto Cave, Yarrangobilly Caves, New South Wales, Australia [35.43 S; $148.29^{\circ} \mathrm{E} ; 935 \mathrm{~m}$ Australian Height Datum (AHD)] in 2012 (Fig. 1) under New South Wales Parks and Wildlife Scientific licence SL100538. The caves are located at the northern end of the Snowy Mountains, at an elevation where the water balance changes from an energy (demand) to supply (precipitation) limited system ${ }^{23,24}$. The caves were formed through karstification of the Yarrangobilly Limestone, a massive Silurian limestone formation with an extent of $\sim 1.4 \mathrm{~km}$ by $14 \mathrm{~km}$ and a maximum depth of $\sim 450 \mathrm{~m}^{25}$. Past work has concluded that reduced rainfall invokes prior calcite precipitation (PCP) at Yarrangobilly and hence up (down) trend in $\mathrm{Mg} / \mathrm{Ca}$ ratios implies increased (decreased) drip water contact time under drier (wetter) conditions ${ }^{26,27}$.

The present day climate of the Yarrangobilly area is influenced by the northern extension of the mid-latitude westerly winds. It experiences cool to cold montane temperatures through winter, while in summer warm to hot and dry conditions dominate under the influence of the subtropical ridge. Major Southern Hemisphere ocean-atmosphere teleconnections including the ENSO, Southern Annular Mode (SAM), PDO, and IOD all affect the regional climate state ${ }^{28-32}$. Rain bearing weather systems that affect Yarrangobilly Caves may originate from the tropics and the southern mid-latitudes ${ }^{33,34}$. Mean annual precipitation is approximately $1147 \mathrm{~mm}$, with a mean annual temperature of $12^{\circ} \mathrm{C}^{35,36}$. The most effective precipitation occurs during the cool, wet winter ${ }^{36,37}$ and while snow may fall, the site is below the seasonal snowline and no snowpack remains through winter. Temperature logging from where GC001 was collected in the Grotto Cave found mean internal cave temperature was $8.8^{\circ} \mathrm{C}$ during the study (August 2014 to February 2015). 


\section{Results}

The Mg time series for GC001 (Fig. 2a) shows clear cycles of higher/lower concentrations with a marked increase occurring around 120,800 years BP. This period of elevated Mg concentrations prevailed until around 118,500 years BP. It then remained mostly stable until a sharp decrease at approximately 117,850 years BP. This period of higher Mg concentrations (drier) in GC001 aligns with a period of increased depletion of $\delta^{18} \mathrm{O}$ in a speleothem from northern Borneo ${ }^{38}$ indicating wetter conditions there (Fig. 2d), indicative of a more northerly position of the ITCZ. It also correlates with periods of increased dust deposition recorded at Dome C, Antarctica (Fig. 2e). Australia is a known source of interglacial dust to the Antarctic ${ }^{39,40}$. Accordingly, we infer drier conditions in southeast Australia as indicated by higher Mg concentrations from 120,800 to 118,500 years BP in GC001 sustained regional mega-drought(s) across this period with associated wind erosion contributing to increased dust flux at Dome C, Antarctica such as between 119,050 to 120,300 years BP (Fig. 2e). Slightly higher dust flux values from 117,500 to 117,800 years BP (Fig. 2e) may have also originated from southeast Australia but do not correlate with elevated $\mathrm{Mg}$ concentrations in GC001 (Fig. 2a), or any notable signal in the $\delta^{18} \mathrm{O}$ record from northern Borneo (Fig. 2d).

The Sr time series (Fig. 2b) displays some periods of higher/lower concentrations that are concurrent with variability in the Mg record (Fig. 2a), such as around 121,000 years BP. However, unlike the Mg record, the Sr time series exhibits an overall trend of decreasing concentrations with the period between approximately 120,800 years to 118,500 years BP remaining relatively constant at approximately $25 \mathrm{ppm}$, before decreasing more quickly. This is similar to the Ba concentrations time series (Fig. 2c) which is strongly correlated with Sr $\left(\mathrm{R}^{2}=0.80, \mathrm{n}=3980\right)$ reflecting a reduced growth rate (less drip water) under the drier conditions known to have minimal impact on $\mathrm{Mg}$ concentrations ${ }^{43}$. Ba concentrations do display a more consistent decreasing trend that flattens between 120,800 and 119,100 years BP before decreasing further after 118,500 years BP. While exogenic factors such as dust may have affected the Ba record, this is not distinguishable in Fig. $2 \mathrm{c}$ when compared to records such that shown in Fig. 2e. The decreasing trends in the Sr and Ba concentrations correlate with the MIS 5e temperature anomaly reconstruction for Dome C, Antarctic (Fig. 2f) and MIS 5e SST reconstructions from northwest of Australia and east of New Zealand ${ }^{44,45}$. Accordingly, the $\mathrm{Mg}, \mathrm{Sr}$ and Ba concentrations in GC001 collectively record the onset of a prolonged drier period from around 120,750 years BP to 118,500 years BP (Fig. 2) that was associated with increased atmospheric dust and a cooling in atmospheric and ocean temperatures from MIS 5e maximums.

Normalised Lomb-Scargle periodograms for $\mathrm{Mg}$, Sr and Ba were calculated to test for the influence of teleconnection and/or solar cycle forcing on the MIS 5e climate of southeast Australia (Fig. 3). The periodograms show common peaks in spectral density around 200 yrs which align with the de Vries solar cycle $(\sim 205 \text { years })^{46}$. Spectral peaks are also found from $1147 \mathrm{yrs}(\mathrm{Mg})$ to $1268 \mathrm{yrs}(\mathrm{Sr})$ and are within the range of the 1000 year Eddy solar cycle ${ }^{47,48}$. The Sr and Ba records have peaks at $\sim 66.8$ and 88.6 years, which match with the PDO and Gleissberg solar cycle respectively and display coherent spectral peaks at 301.3 years, 454.8 years, 602.7 years and at 3443.8 years. The 301.3 years and 454.8 years cycles are close to the 300 year and 470 year cycles found in sediments from Jeju Island, South Korea ${ }^{49}$. These have been attributed to solar forcing along with the 3443.8 year cycle, which is aligned with the 3300 year Holocene cycles in the $\delta^{18} \mathrm{O}$ record from GISP2 ${ }^{49,50}$. The Mg record displays a strong 709 year cycle that may be a harmonic of the 1400 year cycle found in glacial and interglacial periods in Mg/Ca derived SST records from the South China Sea ${ }^{51}$. Accordingly, the geochemistry of GC001 displays cyclic variability indicative of climate variability forced by both teleconnections and solar cycles recorded globally in geologic archives.

Wavelet transforms for $\mathrm{Mg}$, Sr and Ba presented in Fig. 4 show regions of significant periodicity outlined in black (95\% confidence level). All three elements display significant 4 to 8 year cycles that we interpret as ENSO and around 20 to $30 \mathrm{yrs}$, and 50 to $65 \mathrm{yrs}$, which are indicative of the PDO. While caution is required in attributing shorter-duration cycles given laser ablation sampling resolution, the $\mathrm{Mg}$ record shows clear gaps in ENSO (4-8 year) cycles from approximately 121,500 years BP to around 120,500 years BP. These coincide with a change in $\mathrm{Mg}$ concentrations from $\sim 140$ to $\sim 200 \mathrm{ppm}$ indicating a transition to drier conditions, while the period from 118,500 to 117,500 years BP overlaps with the return to $\mathrm{Mg}$ concentrations $\sim 140 \mathrm{ppm}$ suggesting increased moisture availability. PDO like cycles are most common from around 119,800 years BP to 118,500 years BP.

In the Sr wavelet transform diagram (Fig. 4b), the ENSO signals are most frequent from the start of the record to about 122,100 years BP and are concurrent with the occurrence of the multi-decadal PDO like cycle. This longer decadal cyclicity is also evident from 121,500 years BP to 118,500 years BP with evidence of a separate 20 to 30 year cycle and longer 55 to 75 year cycle. The Ba wavelet plot (Fig. 4c) shows also a dominant short duration ENSO signal in the early part of the record that progressively becomes less frequent. The PDO period cycle is not strong and only occurs above the 95\% confidence level occasionally from 123,500 years BP to around 122,200 years BP and again from around 121,000 years BP to 119,500 years BP.

\section{Discussion}

Understanding the causes and frequency of climate variability is essential to inform prediction of future climate. Proxy of climate variability dating from MIS 5e, the most recent warm period with temperatures similar to the present, offer potential to develop this understanding. The Mg MIS 5e record from stalagmite GC001 shows multi-centennial periods of increased $\mathrm{Mg}$ concentration indicating drier climatic conditions in southeast Australia, notably from 118,500 to 120,750 years BP. This period coincides with increased dust flux recorded in Antarctic ice (Fig. 2e). The Sr and Ba concentrations show evidence also of this climate variability (Fig. 2b,c) with trends of decreasing concentrations correlated with cooling air temperatures and SSTs. Collectively, the $\mathrm{Mg}, \mathrm{Sr}$ and Ba records from GC001 with supporting regional paleoclimate records suggest that southeast Australia during MIS 5e experienced multi-centennial periods of reduced precipitation, temperature variability and increased 

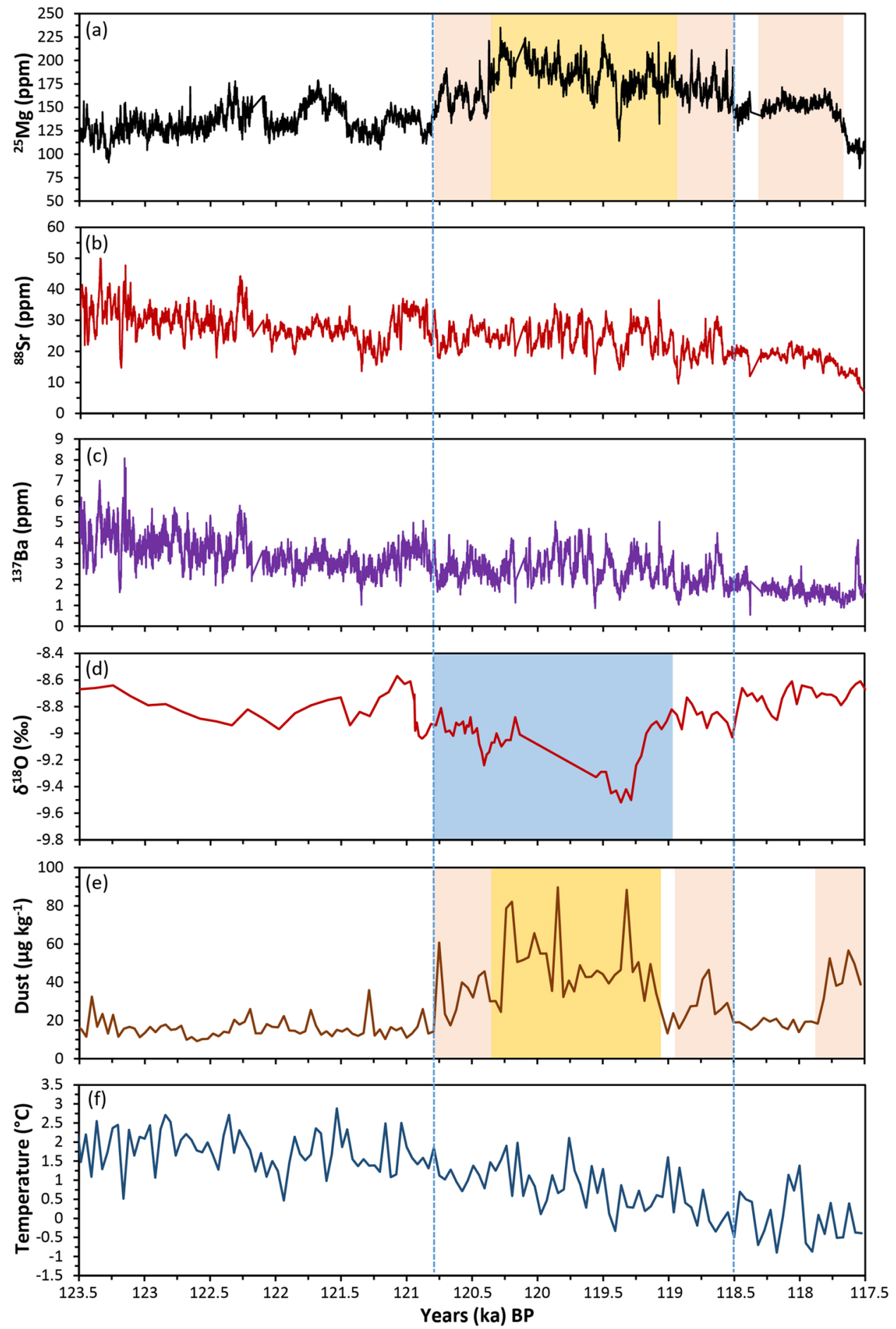

Figure 2. Time series of $\mathrm{Mg}, \mathrm{Sr}$ and $\mathrm{Ba}$ concentrations from $\mathrm{GC} 001(\mathbf{a}-\mathbf{c}) ; \delta^{18} \mathrm{O}$ from a speleothem collected at Whiterock Cave $\left(4^{\circ} 6^{\prime} \mathrm{N}, 114^{\circ} 53^{\prime} \mathrm{E}\right)$, northern $\mathrm{Borneo}^{38}(\mathbf{d})$; dust concentrations from Dome $\mathrm{C}\left(75^{\circ} 06^{\prime} \mathrm{S}\right.$, $\left.123^{\circ} 21^{\prime} \mathrm{E}\right)$, Antarctic $^{41}(\mathrm{e})$, and temperature departure from the average of the past 1000 years Dome C, $\left(75^{\circ} 06^{\prime}\right.$ $\left.\mathrm{S}, 123^{\circ} 21^{\prime} \mathrm{E}\right)$, Antarctic $\mathrm{C}^{42}$ (f). Pink shading indicates periods of intermediate Mg concentrations and dust flux (a,e); yellow shading highest $\mathrm{Mg}$ concentrations and dust flux (a,e) and blue shading (d) corresponding period of depleted $\delta^{18} \mathrm{O}$ indicating wetter conditions in Western Pacific. Vertical dashed blue lines constrain the period interpreted as a mega-drought(s). 

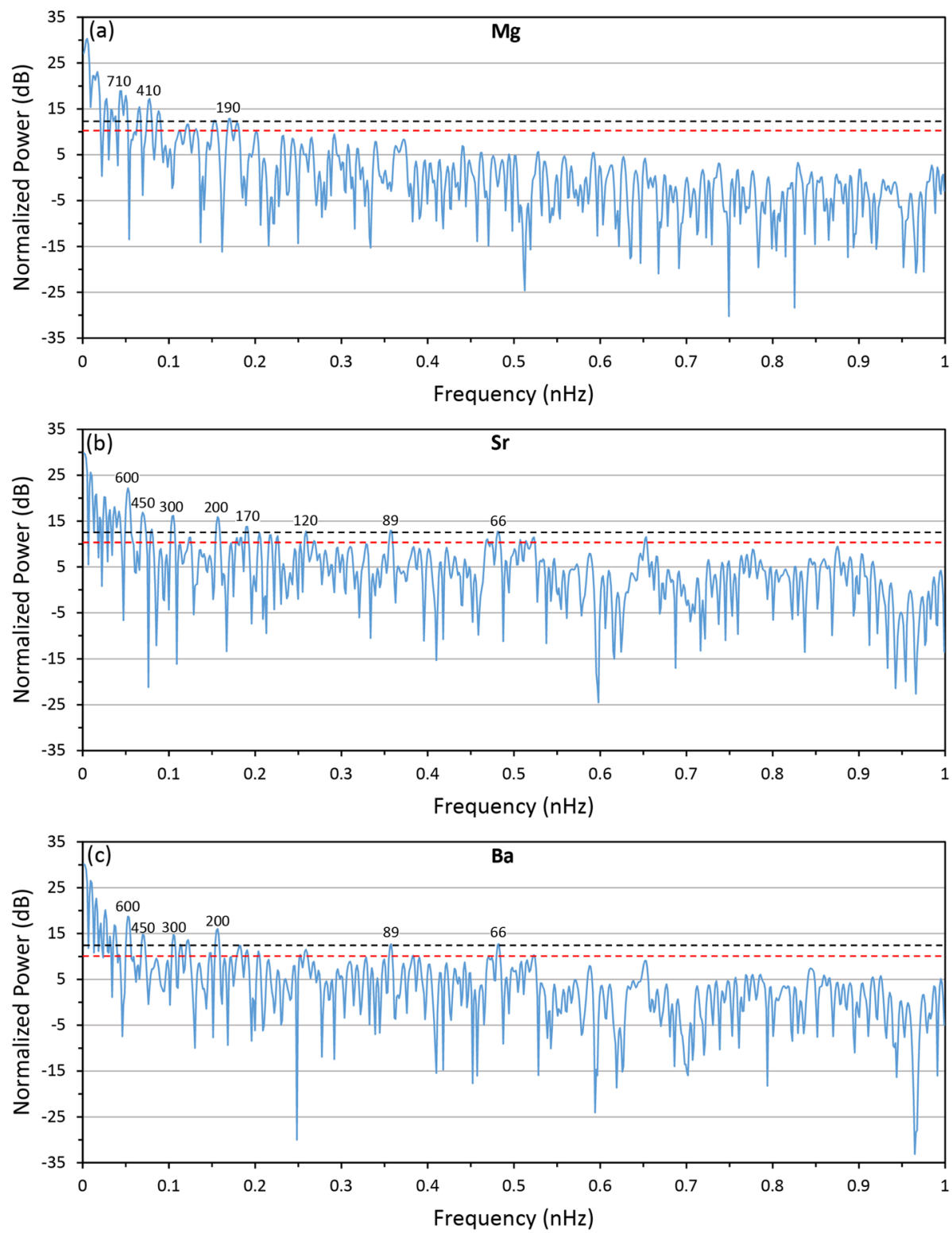

Figure 3. Periodograms of $\mathrm{Mg}, \mathrm{Sr}$ and Ba with 0.9 (red dashed line) and 1.0 probability thresholds shown. Selected dominant periods (annotated) are rounded to the nearest decade.

atmospheric dust. These conditions such as from 118,900 to 120,400 years BP are indicative of mega-droughts (Fig. 2). Superimposed on these multi-centennial periods of drier climatic conditions are higher frequency interannual to interdecadal teleconnections and solar forced cycles of further variability (Fig. 4).

A drier climate during MIS 5e such as from 118,900 to 120,400 years BP would align with results from numerical modelling which found a generally weaker summer monsoon and warmer winter conditions ${ }^{15}$. A weaker monsoon aided by cooler SSTs northwest of Australia at this time ${ }^{5,18}$ would lessen moisture transport into southeast Australia via meridional conveyors such as northwest cloud bands, while warmer temperatures during winter would have increased evaporation, intensifying dry conditions that spanned centuries as evident in our record. Numerical modelling of future climate at $+1.5^{\circ} \mathrm{C}$ indicates that the Australian monsoon may weaken, resulting in an increase in the frequency of dry days ${ }^{52-54}$. Accordingly, the convergence of our paleoclimate record from stalagmite GC001 and published numerical modelling strongly suggest that the climate of southeast Australia will likely become drier throughout the twenty-first century with increased risk of multi-centennial duration dry periods widely referred to as mega-droughts.

The Mg, Sr and Ba records from stalagmite GC001 all display cycles with periodicity of well documented solar and teleconnection forcings of climate. Dominant solar cycles including the Gleissberg solar cycle (88 years), de Vries solar cycle ( 205 years) and possible Eddy solar cycle ( 1000 years) are evident in the geochemistry of GC001. Increases (decreases) in total solar irradiance (TSI) through such cycles result in direct heating (cooling) of the troposphere and Earth's surface. Indirectly, changes in TSI influence galactic cosmic ray (GCR) flux affecting cloud microphysics and cloud cover ${ }^{55}$. Variation in TSI also causes change in ultraviolet (UV) radiation 
(a) $\mathrm{Mg}$

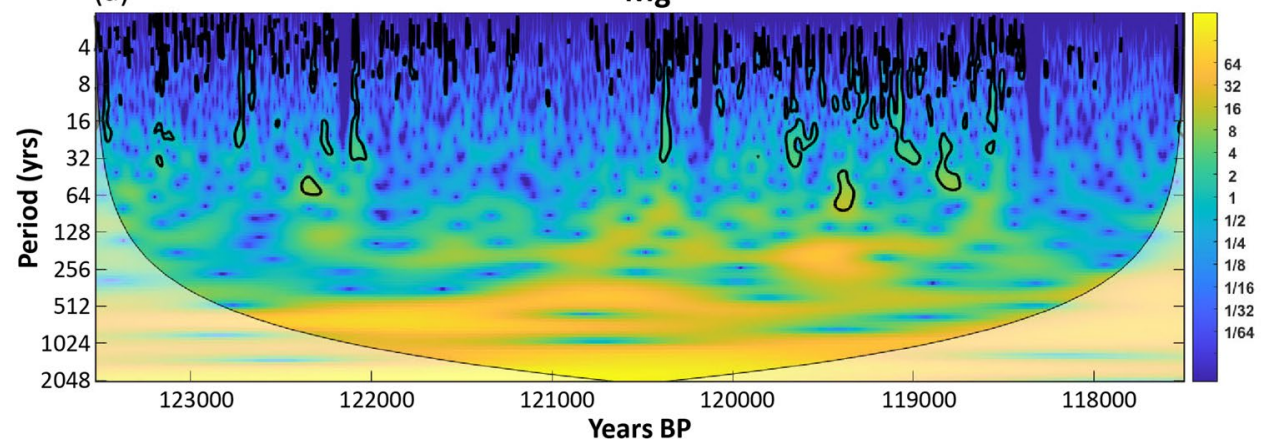

(b)

$\mathrm{Sr}$

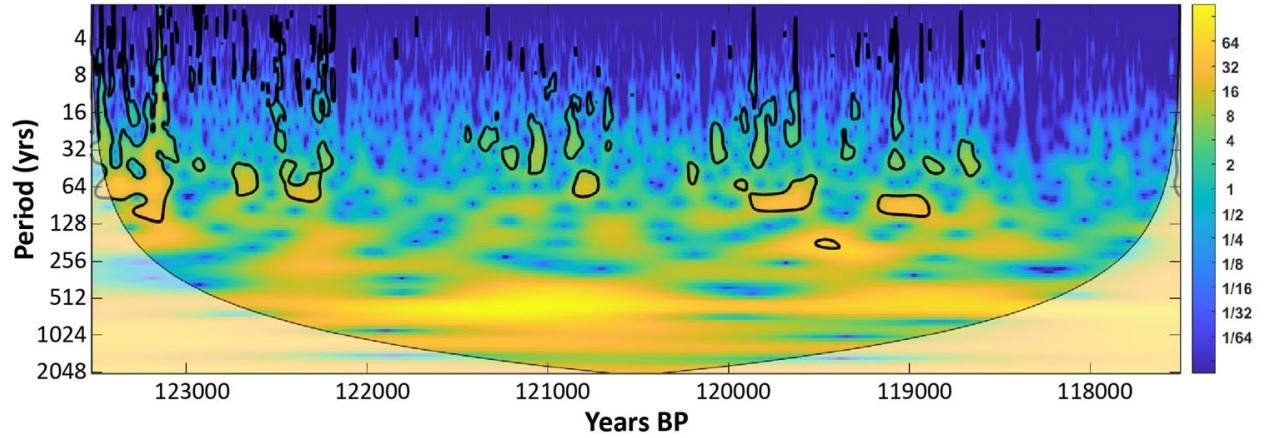

(c)

$\mathrm{Ba}$

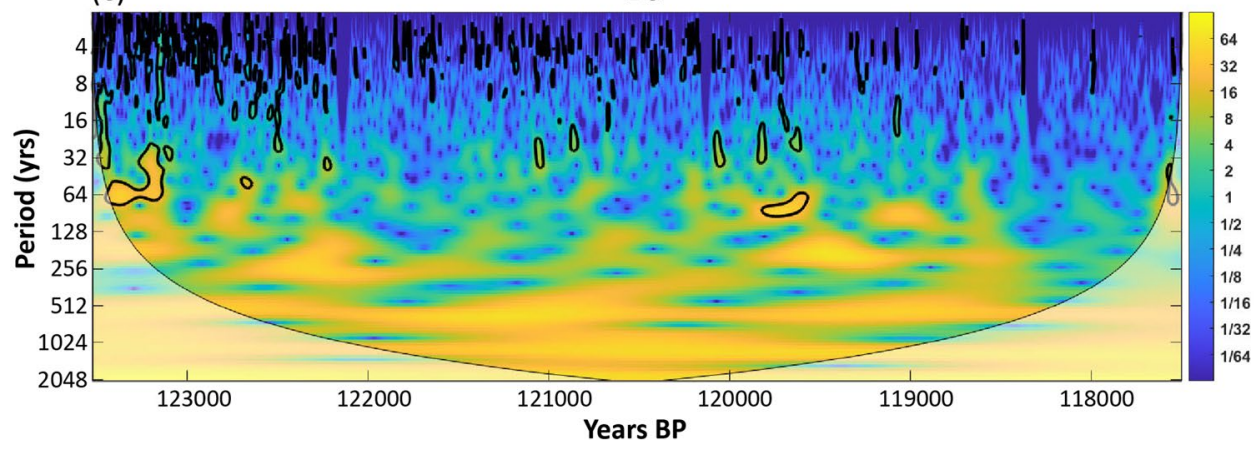

Figure 4. Wavelet plots of $\mathrm{Mg}(\mathbf{a}), \mathrm{Sr}(\mathbf{b})$, and $\mathrm{Ba}$ (c). The thick black lines represent 95\% confidence levels. The lightly shaded region toward the bottom is the Cone of Influence and values in the light region should be considered with caution.

flux, which for a $0.1 \%$ increase in TSI, increases by 4 to $8 \%{ }^{56}$. Concurrently this will increase ozone production in the mid and upper stratosphere through the photolysis of oxygen. Corresponding increases in UV absorption by stratospheric ozone leads to heating and change in the thermal stratification of the atmosphere.

Numerical modelling has shown that enhanced UV heating of the atmosphere corresponding to TSI maxima results in a stratospheric zonal wind anomaly that is most pronounced in the Southern Hemisphere during mid to late winter ${ }^{57}$. Dynamical links between the stratosphere and troposphere caused by such UV forcing lead to change in atmospheric circulation, including jet-stream behaviour, and therefore tropospheric synoptic circulation and ocean dynamics ${ }^{58}$. We therefore postulate that periods of increased TSI contribute to drier conditions (increased Mg in GC001) over southeast Australia in response to increased zonal (westerly) flow and a corresponding more southern track of mid-latitude winter storm systems. This occurs in response to a stronger thermal wind component between the tropics/subtropics and the mid to high latitudes causing a response in atmospheric circulation similar to a more positive SAM. The associated decline in precipitation is recorded clearly in stalagmite GC001 by elevated Mg concentrations and stable to slight decreases in $\mathrm{Sr}$ and Ba concentrations due to reduced speleothem growth, i.e. reduced drip rate ${ }^{43}$ during MIS 5e.

GC001 records 4 to 8 years ENSO-like cycles along with multi-decadal cyclicity indicating PDO type influences-two teleconnections which have been shown to have the greatest impact on the modern climate and in particular rainfall in southeast Australia ${ }^{21,28,59}$. It is therefore reasonable to suggest that these Pacific Ocean teleconnections have been robust and long-lived drivers of interannual and multi-decadal hydroclimate variability in southeast Australia with warm/cool ENSO and PDO phases causing dry/wet periods. 
Evidence of ENSO cycles in GC001 become no longer statistically significant from around 118,200 yrs BP. This is about 500 years before rapid decline in $\mathrm{Mg}$ concentrations, which suggests reduction in drip water residence times and onset of a wetter climate. This change in $\mathrm{Mg}$ and to a lesser amount in $\mathrm{Sr}$ and $\mathrm{Ba}$ correspond to a rapid increase in sea level of around 5 to $6 \mathrm{~m}$ at 118,100 \pm 1400 years BP caused by ice sheet melt ${ }^{60}$. We suggest that this dramatic rise in sea level possibly disrupted ENSO and PDO teleconnections and their impact on the climate of southeast Australia at this time.

Collectively, the MIS 5e climate record developed from GC001 indicates that southeast Australia will likely continue to experience interannual to interdecadal wet-dry cycles driven by teleconnections and solar variability at least until current global warming exceeds Eemian temperatures, possibly within the next decade. However, our record also shows that in a warm interglacial climate such as today or near future, there is risk of multi-centennial periods of less effective precipitation (mega-droughts), initiated by natural variability. Should such prolonged periods of drier conditions occur again, then they may be reinforced by anthropogenic global warming, thereby increasing their severity. As a result, we stress the need for further research into the Eemian climate of Australia and the Southern Hemisphere to resolve the causes of prolonged dry periods during MIS $5 \mathrm{e}$ and to determine their spatial impacts. This will allow new insights to our future climate and the risks it may bring such as drought and associated bushfires.

\section{Methods}

Sample preparation. Six $50 \mathrm{~mm} \times 8 \mathrm{~mm} \times 10 \mathrm{~mm}$ sections sampled from the growth axis of stalagmite GC001 (Fig. 1c) were polished to $1 \mu \mathrm{m}$ and cleaned with Milli-QTM water in an ultrasonic bath, then dried at $60{ }^{\circ} \mathrm{C} .{ }^{43} \mathrm{Ca},{ }^{88} \mathrm{Sr},{ }^{25} \mathrm{Mg}$ and ${ }^{137} \mathrm{Ba}$ data were obtained by Laser-Ablation Inductively-Coupled Plasma MassSpectrometry at the Australian Nuclear Science and Technology Organisation using a Resonetics M50 $193 \mathrm{~nm}$ Excimer laser ablation system coupled to a Varian 820 -ICP MS. A rectangular laser spot $(340 \mu \mathrm{m} \times 50 \mu \mathrm{m})$ and a laser pulse frequency of $10 \mathrm{~Hz}$ was applied with the laser and the narrow side of the rectangle aligned perpendicular to the growth axis, to ensure maximum sampling within the same growth band. Ablation paths were cleaned by laser at a rate of $150 \mu \mathrm{m} \mathrm{s}^{-1}$ prior to analysis at $30 \mu \mathrm{m} \mathrm{s}^{-1}$. Helium $(600 \mathrm{ml} / \mathrm{min})$ carried the ablated sample from the sample cell, before mixing with nitrogen $(5 \mathrm{ml} / \mathrm{min}$ ) and the instrument nebuliser flow (argon at $0.85 \mathrm{~L} / \mathrm{min}$ ) to pass through a smoothing device "The SQUID" before reaching the plasma torch. Mass spectrometry was conducted with a dwell time of $50 \mathrm{~ms}$. All elements were referenced to NIST SRM612. As the NIST glass references are not certified for $\mathrm{Mg}$, the reference value supplied by the Iolite software (77 ppm) was used ${ }^{61}$. Mass spectrometry data were processed with Iolite normalised to ${ }^{43} \mathrm{Ca}$ as the Internal Standard.

Age model. The age model was constructed using an ensemble of 30 iterations of the StalAge algorithm, with $8 \mathrm{U} /$ Th dates which spanned an apparent hiatus in the speleothem's growth (Supplementary information). While age models for stalagmites with known hiatuses can be calculated in discrete sections ${ }^{62}$, StalAge is capable of successfully modelling hiatuses and their increased uncertainty ${ }^{24,62,63}$.

Using StalAge we modelled independently the ages of the two sections either side of the apparent growth hiatus in GC001 as well as one continuous age model using an ensemble of 30 iterations each. The maximum difference between the two discrete age models and the continuous age model for GC001 was just 30 years, well within the $2 \sigma$ error of the ages. As such, we use the one age model over the whole stalagmite. Points between 100 and $140 \mathrm{~mm}$ were excluded to ensure the growth hiatus was avoided. Full uranium-series dating results are presented in Table S1. None of the data post growth hiatus are presented here since this research focused on MIS 5e.

Analysis of geochemical time series. Mineral weathering of the local karst is the dominant source of $\mathrm{Mg}$ and $\mathrm{Sr}$ in speleothems in the Yarrangobilly $\mathrm{caves}^{27}$, with drip-water monitoring showing that $\mathrm{Mg}$ and $\mathrm{Sr}$ (and $\mathrm{Ca}$ ) can be used as paleo-environmental proxies for contrasting rainfall conditions ${ }^{26,27}$. Namely, reduced rainfall invokes prior calcite precipitation (PCP) and increased drip-water concentrations, and hence stalagmite $\mathrm{Mg} / \mathrm{Ca}$ (and at times $\mathrm{Sr} / \mathrm{Ca}$ ) ratios ${ }^{43}$. As drip-water monitoring before GC001 was collected was not possible we calculated the slope of $\ln (\mathrm{Sr} / \mathrm{Ca})$ vs $\ln (\mathrm{Mg} / \mathrm{Ca})(\mathrm{n}=6000$ pairs of ten point running means). A positive correlation with a slope of 0.88 was calculated confirming $\mathrm{Mg}$ and $\mathrm{Sr}$ variations in GC001 are under some form of hydrological control ${ }^{64}$.

Extreme outliers $(>3 \sigma)$ in the time series of ${ }^{25} \mathrm{Mg}$, ${ }^{88} \mathrm{Sr}$ and ${ }^{137} \mathrm{Ba}$ data were removed with the gaps filled using a kalman filter. Three periods of missing data due to saw cuts at 118,292 years BP lasting for 82 years, at 120,104 years BP lasting for 64 years and, at 122,099 years BP lasting for 80 years were filled also using a kalman filter. Lomb-Scargle periodograms, which are commonly used in frequency analysis of unequally spaced data including paleo-environmental data, were then developed using the raw filtered data. The data was then resampled at 1 year time steps, using linear interpolation, prior to calculating the wavelet transforms.

\section{Data availability}

All data used in this research is archived and accessible through The University of Queensland eSpace Library or by contacting HM.

Received: 22 June 2020; Accepted: 8 October 2020

Published online: 22 October 2020

\section{References}

1. Masson-Delmotte, V. et al. Past temperature reconstructions from deep ice cores: Relevance for future climate change. Clim. Past. 2, 145-165 (2006). 
2. Lunt, D. J. et al. A multi-model assessment of last interglacial temperatures. Clim. Past. 9, 699-717 (2013).

3. Chadwick, M., Allen, C. S., Sime, L. C. \& Hillenbrand, C.-D. Analysing the timing of peak warming and minimum winter sea-ice extent in the Southern Ocean during MIS 5e. Q. Sci. Rev. 229, 106-134 (2020).

4. Clark, P. \& Huybers, P. Interglacial and future sea level. Nature 462, 856-857 (2009).

5. Hoffman, J. S., Clark, P. U., Parnell, A. C. \& He, F. Regional and global sea surface temperatures during the last interglaciation. Science 355, 276-279 (2017).

6. Tzedakis, P. C. et al. Enhanced climate instability in the North Atlantic and southern Europe during the Last Interglacial. Nat. Commun. 9, 4235. https://doi.org/10.1038/s41467-018-06683-3 (2018).

7. Salonen, J. S. et al. Abrupt high-latitude climate events and decoupled seasonal trends during the Eemian. Nat. Commun. 9, 2851. https://doi.org/10.1038/s41467-018-05314-1 (2018).

8. Rasmussen, S. O. et al. A stratigraphic framework for abrupt climatic changes during the Last Glacial period based on three synchronized Greenland ice-core records: Refining and extending the INTIMATE event stratigraphy. Q. Sci. Rev. 106, 14-28 (2014).

9. Chapman, M. R. \& Shackleton, N. J. Global ice-volume fluctuations, North Atlantic ice-rafting events, and deep-ocean circulation changes between 130 and $70 \mathrm{ka}$. Geology 27, 795-798 (1999).

10. Hennessy, K. J. \& Pittock, A. B. Greenhouse warming and temperature threshold events in Victoria, Australia. Int. J. Climatol. 15(6), 591-612 (1995)

11. Cai, W., Purich, A., Cowan, T., van Rensch, P. \& Weller, E. Did climate change-induced rainfall trends contribute to the Australian Millennium Drought?. J. Clim. 27, 3145-3168 (2014).

12. Sharples, J. J. et al. Natural hazards in Australia: Extreme bushfire. Clim. Change. 139, 85-99. https://doi.org/10.1007/s10584-0161811-1 (2016).

13. Kirono, D. G. C., Hennessy, K. J. \& Grose, M. R. Increasing risk of months with low rainfall and high temperature in southeast Australia for the past 150 years. Clim. Risk Manag. 16, 10-21 (2017).

14. Nikolova, I., Yin, Q., Berger, A., Singh, U. K. \& Karami, M. P. The last interglacial (Eemian) climate simulated by LOVECLIM and CCSM3. Clim. Past. 9, 1789-1806 (2013).

15. Pedersen, R.A., Langen, P.L. \& Vinther, B.M. The last interglacial climate: Comparing direct and indirect impacts of insolation changes. Clim. Dyn. 48, 3391-3407.

16. Fu, X., Cohen, T. J. \& Arnold, L. J. Extending the record of lacustrine phases beyond the last interglacial for Lake Eyre in central Australia using luminescence dating. Q. Sci. Rev. 162, 88-110 (2017).

17. Khon, V. C., Schneider, B., Latif, M., Park, W. \& Wengel, C. Evolution of eastern equatorial Pacific seasonal and interannual variability in response to orbital forcing during the Holocene and Eemian from model simulations. Geophys. Res. Lett. 45, 9843-9851 (2018).

18. McCulloch, M. T. \& Esat, T. The coral record of last interglacial sea levels and sea surface temperatures. Chem. Geol. 169(1-2), $107-129$ (2000).

19. Ummenhofer, C. C. et al. What causes southeast Australia's droughts?. Geophys. Res. Lett. 36, L04706 (2009).

20. Cai, W. et al. Pantropical climate interactions. Science. 363, eaav4236, https://doi.org/10.1126/science.aav4236 (2019).

21. Verdon, D. C., Wyatt, A. M., Kiem, A. S. \& Franks, S. W. Multidecadal variability of rainfall and streamflow: Eastern Australia. Water Resour. Res. 40(10), W10201. https://doi.org/10.1029/2004WR003234 (2004).

22. Verdon, D. C. \& Franks, S. W. Long-term behaviour of ENSO: Interactions with the PDO over the past 400 years inferred from paleoclimate records. Geophys. Res Lett. 33, L07612 (2006).

23. Reinfelds, I., Swanson, E., Cohen, T., Larsen, J. \& Nolan, A. Hydrospatial assessment of streamflow yields and effects of climate change: Snowy Mountains, Australia. J. Hydrol. 512, 206-220 (2014).

24. McGowan, H.A., Soderholm, J.S., Callow, N.J., McGrath, G.S. \& Campbell, M.L. Global warming in the context of 2000 years of Australian alpine temperature and snow cover. Sci. Rep.-UK, 10.1038/s41598-018-22766-z (2018).

25. Geoscience Australia. Yarrangobilly Limestone. Australian Stratigraphic Units Database. https://dbforms.ga.gov.au/pls/www/geodx .strat_units.sch_full?wher=stratno=20888 (2007).

26. Tadros, C. V. et al. ENSO-cave drip water hydrochemical relationship: A 7-year dataset from south-eastern Australia. Hydrol. Earth Syst. Sci. 20, 4625-4640. https://doi.org/10.5194/hess-20-4625-2016 (2016).

27. Tadros, C. V., Treble, P. C., Baker, A., Hankin, S. \& Roach, R. Cave drip water solutes in south-eastern Australia: Constraining. Sci. Total Environ. 651, 2175-2186 (2019).

28. McBride, J. L. \& Nicholls, N. Seasonal relationships between Australian rainfall and the southern oscillation. Mon. Weather Rev. 111, 1998-2004 (1983).

29. Ashok, K., Guan, Z. \& Yamagata, Y. Influence of the Indian Ocean dipole on the Australian winter rainfall. Geophys. Res. Lett. 30(15), 2003. https://doi.org/10.1029/2003GL017926 (1821).

30. McGowan, H. A., Marx, S. K., Denholm, J., Soderholm, J. \& Kamber, B. K. Reconstructing annual inflows to the headwater catchments of the Murray River, Australia, using the Pacific Decadal Oscillation. Geophys. Res. Lett. 36, L06707. https://doi. org/10.1029/2008GL037049 (2009).

31. Ashcroft, L., Gergis, J. \& Karoly, D.J. Long-term stationarity of El Niño-southern oscillation teleconnections in southeastern Australia. Clim. Dyn. 46, 2991-3006, https://doi.org/10.1007/s00382-015-2746-3 (2016)

32. Theobald, A. \& McGowan, H. Evidence of increased tropical moisture in south-east Australian alpine precipitation during ENSO. Geophys. Res. Lett. 43, https://doi.org/10.1002/2016GL070767 (2016).

33. Callow, N., McGowan, H., Warren, L. \& Speirs, J. Precipitation stable isotope variability in a modest altitude alpine setting, Snowy Mountains, Australia. J. Geophys. Res. Atmos., https://doi.org/10.1002/2013JD020710 (2014).

34. Theobald, A., McGowan, H. \& Speirs, J. Trends in synoptic circulation and precipitation in the Snowy Mountains region, Australia, in the period 1958-2012. Atmos. Res. https://doi.org/10.1016/j.atmosres.2015.05.007 (2015).

35. Desmarchelier, J.M. High-Resolution Palaeoenvironmental Information from Southeast Australian Speleothems. (PhD Thesis, University of Tasmania, Hobart, 2000).

36. Australian Bureau of Meteorology. Yarrangobilly Caves: Station Number 72141. https://www.bom.gov.au/climate/data/stations/ (2014).

37. Campbell, M. L., Callow, J. N., McGrath, G. S. \& McGowan, H. A. A geophysical approach to inform epikarst drip water modelling: Implications for palaeo-climate reconstruction. Hydrol Process. https://doi.org/10.1002/hyp.11392 (2017).

38. Carolin, S.A. et al. Northern Borneo stalagmite records reveal West Pacific hydroclimate across MIS 5 and 6. Earth Planet Sci. Lett. 439, 182-193, https://doi.org/10.1016/j.epsl.2016.01.028 (2016)

39. Revel-Rolland, M. et al. Eastern Australia: A possible source of dust in East Antarctica Interglacial ice. Earth Planet. Sci. Lett. 249, $1-13$ (2006).

40. McGowan, H. A. \& Clark, A. Identification of dust transport pathways from Lake Eyre, Australia using Hysplit. Atmos. Environ. 42(29), 6915-6925 (2008).

41. Lambert, F. et al. Dust-climate couplings over the past 800,000 years from the EPICA Dome C ice core. Nature 452, 616-619 (2008).

42. Jouzel, J. et al. Orbital and millennial Antarctic climate variability over the past 800,000 years. Science 317(5839), 793-796 (2007).

43. Treble, P., Shelley, J. M. G. \& Chappell, J. Comparison of high resolution sub-annual records of trace elements in a modern (1911-1992) speleothem with instrumental climate data from southwest Australia. Earth Planet Sci. Lett. 216(1-2), 141-153 (2003). 
44. Pahnke, K. \& Sachs, J. P. Sea surface temperatures of southern mid-latitudes 0-160 kyr B.P. Paleoceanography, 21, PA2003, https ://doi.org/10.1029/2005PA001191 (2006).

45. Xu, J., Kuhnt, W., Holbourn, A., Andersen, N. \& Bartoli, G. Magnesium/calcium ratios and sea surface temperatures on sediment surface samples of the Timor Sea. PANGAEA https://doi.org/10.1594/PANGAEA.472296 (2006).

46. Raspopov, O. M. et al. The influence of the de Vries ( 200-year) solar cycle on climate variations: Results from the Central Asian Mountains and their global link. Palaeogeogr. Palaeoecol. 259, 6-16 (2008).

47. Obrochta, S. P., Miyahara, H., Yokoyama, Y. \& Crowley, T. J. A re-examination of evidence for the North Atlantic "1500-year cycle" at Site 609. Q. Sci. Rev. 55, 23-33 (2012).

48. Li, Y. et al. Multiscale monsoon variability during the last two climatic cycles revealed by spectral signals in Chinese loess and speleothem records. Clim. Past. 11, 1067-1075 (2015).

49. Park, J. Solar and tropical ocean forcing of late-Holocene climate change in coastal East Asia. Palaeogeogr. Palaeoecol. 469, 74-83 (2017).

50. Stuiver, M., Grootes, P. M. \& Braziunas, T. F. The GISP $2 \delta^{18} \mathrm{O}$ climate record of the past 16,500 years and the role of the Sun, ocean and volcanoes. Q. Res. 44, 341-354 (1995).

51. Jin, H. \& Jian, Z. Millennial-scale climate variability during the mid-Pleistocene transition period in the northern South China Sea. Q. Sci. Rev. 70, 15-27 (2013).

52. Menon, A., Levermann, A., Schewe, J., Lehmann, J. \& Frieler, K. Consistent increase in Indian monsoon rainfall and its variability across CMIP-5 models. Earth Syst. Dyn. 4, 287-300 (2013).

53. Reisinger, A., et al. Australasia. in Climate Change 2014: Impacts, Adaptation, and Vulnerability. Part B. Regional Aspects 1371-1438. (Cambridge University Press, Cambridge, 2014).

54. Chevuturi, A., Klingaman, N. P., Turner,A. G. \& Hannah, S. Projected changes in the Asian-Australian monsoon region in $1.5^{\circ} \mathrm{C}$ and $2.0^{\circ} \mathrm{C}$ global-warming scenarios. Earth's Future 6, 339-358 (2018).

55. Gray, L. J. et al. Solar influences on climate, Rev. Geophys. 48, RG4001, https://doi.org/10.1029/2009RG000282 (2010).

56. Zastrow, M. Model of solar cycle's impact on climate gets upgrade. Eos 96,https://doi.org/10.1029/2015EO040587 (2015).

57. Hood, L. L. et al. Solar signals in CMIP-5 simulations: The ozone response. Q. J. R. Meteorol. Soc. https://doi.org/10.1002/qj.2553 (2015).

58. Kidston, J. et al. Stratospheric influence on tropospheric jet streams, storm tracks and surface weather. Nat. Geosci. 8, 433-440 (2015).

59. Henley, B. J., Thyer, M. A., Kuczera, G. \& Franks, S. W. Climate-informed stochastic hydrological modeling: Incorporating decadalscale variability using paleo data. Water Resour. Res. 47, W11509. https://doi.org/10.1029/2010WR010034 (2011).

60. O'Leary, M. et al. Ice sheet collapse following a prolonged period of stable sea level during the last interglacial. Nat. Geosci. 6 , 796-800. https://doi.org/10.1038/ngeo1890 (2013).

61. Paton, C., Hellstrom, J., Paul, B., Woodhead, J. \& Hergt, J. Iolite: Freeware for the visualisation and processing of mass spectrometric data. J. Anal. Atom Spectrom. 26(12), 2508 (2011).

62. Scholz, D. \& Hoffmann, D. L. StalAge-An algorithm designed for construction of speleothem age models. Quat. Geochronol. 6(3-4), 369-382 (2011).

63. Scholz, D., Hoffmann, D. L., Hellstrom, J. \& Ramsey, C. B. A comparison of different methods for speleothem age modelling. Quat. Geochronol. 14, 94-104 (2012).

64. Sinclair, D. et al. Magnesium and strontium systematics in tropical speleothems from the Western Pacific. Chem. Geol. 294-295, $1-17$ (2012).

\section{Acknowledgements}

This work was funded by Snowy Hydro Ltd., with the support of The University and Queensland and The University of Western Australia. Mr George Bradford, Manager of Yarrangobilly Caves is thanked for his support and assistance with identification and collection of stalagmite GC001 under New South Wales Parks and Wildlife Scientific licence SL100538. Technical assistance with the analysis of GC001 was kindly provided by Chris Vardanega and Brett Rowling at the Australian Nuclear Science and Technology Organisation, Lucas Heights, Sydney. MC was supported an Australian Postgraduate Award Scholarship and an Australian Government Research Training Program (RTP) Scholarship, UWA Safety Net Top-Up Scholarship, an Australian Institute of Nuclear Science and Engineering Postgraduate Research Award. Tim Cohen, Wollongong University; Robert Jamieson, University of Leeds and one anonymous reviewer are thanked for their constructive comments on an earlier version of the manuscript.

\section{Author contributions}

H.M. wrote the manuscript and with J.N.C. devised and supervised the research including the identification and collection of the stalagmite. M.C. undertook the analysis of GC001 and development of the age model. A.L. undertook the numerical analyses of the geochemical data and prepared Figures 4 \&amp; 5. H.W. supervised geochemical analyses. All authors discussed the results and contributed to finalisation of the manuscript.

\section{Competing interests}

The authors declare no competing interests.

\section{Additional information}

Supplementary information is available for this paper at https://doi.org/10.1038/s41598-020-75071-z.

Correspondence and requests for materials should be addressed to H.M.

Reprints and permissions information is available at www.nature.com/reprints.

Publisher's note Springer Nature remains neutral with regard to jurisdictional claims in published maps and institutional affiliations. 
(c) (i) Open Access This article is licensed under a Creative Commons Attribution 4.0 International cc) License, which permits use, sharing, adaptation, distribution and reproduction in any medium or format, as long as you give appropriate credit to the original author(s) and the source, provide a link to the Creative Commons licence, and indicate if changes were made. The images or other third party material in this article are included in the article's Creative Commons licence, unless indicated otherwise in a credit line to the material. If material is not included in the article's Creative Commons licence and your intended use is not permitted by statutory regulation or exceeds the permitted use, you will need to obtain permission directly from the copyright holder. To view a copy of this licence, visit http://creativecommons.org/licenses/by/4.0/.

(C) The Author(s) 2020 